\title{
The composition and structure of jeanbandyite and natanite
}

\author{
J. BETTERTON \\ 21 Linkway, Edgcumbe Park, Crowthorne, Berkshire, RG45 6ES, UK \\ D. I. GRI:I:N \\ Manchester Museum, The University, Manchester, Ml3 9PL, UK \\ C. JI:WSON \\ Lower Carneggy Cottage, (ireenbottom, Truro, Comwall, TR4 8QL, UK \\ J. SPRATT AND P. TANDY \\ Department of Mineralogy, Natural History Muscum, Cromwell Road, London, SW7 5BD, UK
}

\section{ABSTR ACT}

The rare iron-tin hydroxide minerals natanite and jeanbandyite occur as small pseudo-octahedral crystals in high-temperature Sn-Cu-As veins at Penberthy Croft Mine and Hingston Downs Quarry, Cornwall. The lattice parameters for jeanbandyite and natanite are reported and compared to previously calculated values. The chemical composition of jeanbandyite is discussed and a significant proportion of divalent $\mathrm{Fe}$ and $\mathrm{Mn}$ is shown to be present.

Keywords: Cornwall, jeanbandyite, natanite.

JEANBANDYITE and natanite are closely related iron-tin hydroxide minerals which typically crystallise at a late stage in high-temperature hydrothermal Sn-W-As veins. The chemical formula of jeanbandyite is idealised as $\left(\mathrm{Fe}_{1}^{3+}, \square_{x}\right)\left(\mathrm{Sn}_{1-x}^{4+}, \square_{y}\right)(\mathrm{OH})_{6}$ with $3 x+4 y=1$ and $\square$ indicating a vacancy (Kampf, 1982). Natanite is chemically similar, the ideal formula being $\mathrm{Fe}^{2 \cdot} \mathrm{Sn}^{4}(\mathrm{OH})_{6}$ (Marshukova et al., 1981).

The type locality for jeanbandyite is at Llallagua, Bolivia, and the only other confirmed records are from Santa Eulalia, Chihuahua, Mexico (Kampf, 1982) and the Mount Plcasant mine, New Brunswick, Canada (R. Bideaux, pers. comm.). The type locality for natanite is the Trudov (and Mushiston) tin deposit in Tadzhikistan, Central Asia; it also occurs in the Chat-Karagai tin ores (Marshukova et al., 1981), and with jeanbandyite at Santa Eulalia, Chihuahua, Mexico (Kampf, 1982). Natural FeSn $(\mathrm{OH})_{6}$ occurs at Tsumeb, Namibia (Geier and Otteman, 1970), and at a tin deposit in Malaya (Grubb and Hannaford, 1966), but it is not

(1998 The Mineralogical Society clear whether this is jeanbandyite, natanite or an intergrowth of the two.

\section{Experimental}

A combination of techniques is required to identify jeanbandyite and natanite. Their structural similarities to other members of the stottite and schoenfliesite groups means that identifications based solely on X-ray powder diffraction data must be treated with caution. Chemically, they differ very slightly in their stoichiometry and in the oxidation state of the iron which is largely present as $\mathrm{Fe}^{3+}$ in jeanbandyite as compared to $\mathrm{Fe}^{2+}$ in natanite.

Specimens from Penberthy Croft Mine were identified at the Natural History Museum (London) using a combination of X-ray diffractometry and electron probe microanalysis. The X-ray diffraction pattern was recorded, using a $114.6 \mathrm{~mm}$ diameter Debye-Scherrer camera and $\mathrm{Cu}-K \alpha$ radiation. Chemical analyses were performed on a resin-embedded polished crystal fragment using a 


\section{J. BETTERTONETAL.}

Cameca SX50 wavelength-dispersive microprobe operating at $15 \mathrm{kV}$ and $20 \mathrm{nA}$. Since the morphology of jeanbandyite and natanite are useful indicators of their identity, two groups of crystals were examined in an ISI ABT55 SEM with an environmental chamber, allowing imaging of uncoated specimens at low pressure.

Specimens from Hingston Downs Quarry were identified at Manchester University using a combination of polarized light microscopy, Xray diffractometry, electron probe microanalysis, and wet chemistry. Crystal grains were mounted in epoxy resin on a probe slide, and a polished grain mount $100 \mu \mathrm{m}$ thick produced. The mounted grains were examined by polarized light microscopy to detcrmine their optical properties (since jeanbandyite is tetragonal while natanite is cubic). Quantitative analyses were subsequently performed using a Cameca Camebax electron probe microanalyser operating at $15 \mathrm{kV}, 20 \mathrm{nA}$ and fitted with a Link A10/85s Xray analyser using SPECTRA ED/WD automation software. A Link ZAF4 correction model was applied to the raw data and the compositions calculated as wt.\% oxides. Details of the calibration standards used are given in Table 1 . The oxidation state of iron in the crystals was determined using microchemical tests. Crystal fragments for powder diffractometry were finely ground and applied in a solvent suspension onto a glass slide; evaporation of the solvent left a thin uniform film of powder on the slide surface. The slide was mounted in a Philips diffractometer and the powder diffraction pattern recorded at 0.02

TABLF. 1. Quantitative chemical data for jeanbandyite from Hingston Downs Quarry. The data are based on nine analyses on three separate crystal fragments. Water was calculated by difference. Standards used were: $\mathrm{Mg}$, periclase; Si, wollastonite; $\mathrm{Mn}$, tephroite; Fe, fayalite; $\mathrm{Sn}$ tin metal

\begin{tabular}{lrc}
\hline Oxide & Weight $\%$ & (Range) \\
\hline $\mathrm{MgO}$ & 0.52 & $(0.36-0.84)$ \\
$\mathrm{SiO}_{2}$ & 1.12 & $(0.81-1.32)$ \\
$\mathrm{MnO}$ & 3.83 & $(3.27-4.48)$ \\
$\mathrm{FeO}$ & 19.46 & $(18.68-20.34)$ \\
$\mathrm{SnO}_{2}$ & 52.59 & $(51.88-53.66)$ \\
$\mathrm{H}_{2} \mathrm{O}$ & 22.48 & $(20.72-23.55)$ \\
Total & 100.0 & \\
\hline
\end{tabular}

intervals in $2 \theta$. Silicon was used as an internal standard to check the accuracy of the diffractometer where lattice constants were being determined.

\section{Occurrence}

Jeanbandyite and natanite occur at two localities in Cornwall: Penberthy Croft Mine. St Hilary, and Hingston Downs Quarry, Calstock. These are the first reports of the minerals from the British Isles.

\section{Penberthy Croft Mine}

Penberthy Croft Mine [national grid reference SW 555 324] produced copper, tin and lead from a scries of east-west lodes emplaced in Devonian metasediments consisting of low-grade greenschist-facies slates known locally as killas. The orebodics cxploited by the mine are now inaccessible. However, examination of dump matcrial suggests they contained a number of distinet mineral assemblages including early hightemperature hydrothermal Sn-As-W-Cu veins, later lower-temperature mesothermal to epithermal $\mathrm{Pb}-\mathrm{Zn}$ mineralisation, and late-stage low-temperature Fe-Mn mineralisation. Supergene oxidation has produced a wide variety of secondary minerals which (in order of approximate abundance) include arsenates, sulphates, arsenate-sulphates and phosphates (c.g. Camm and Merry, 1991).

At Penberthy Croft Mine, jeanbandyite occurs in intimate intergrowth with natanite in lustrous, yellow, transparent to translucent, pscudo-octahedral crystals up to $0.4 \mathrm{~mm}$ across. The best developed crystal form is always the pyramid $\{111\}$ whereas the prism $\{100\}$ and pinacoid $\{001$ are usually present although minute (Fig. 1). The crystals occur in high-temperature vcins containing major quartz and arsenopyrite, minor sphalerite and a chlorite-group mineral and rare galena. Very few specimens were collected despite a thorough search of the minc dumps and it is elcar that they are very rarc.

\section{Hingston Downs Quarry}

Hingston Downs Quarry [national grid reference SX 409719$]$ is situated on the Cornish side of the Tamar river valley above the village of Gunnislake. It produces roadstone from an isolated microgranite boss between Dartmoor and Bodmin Moor. 


\section{JEANBANDYITE AND NATANITE}

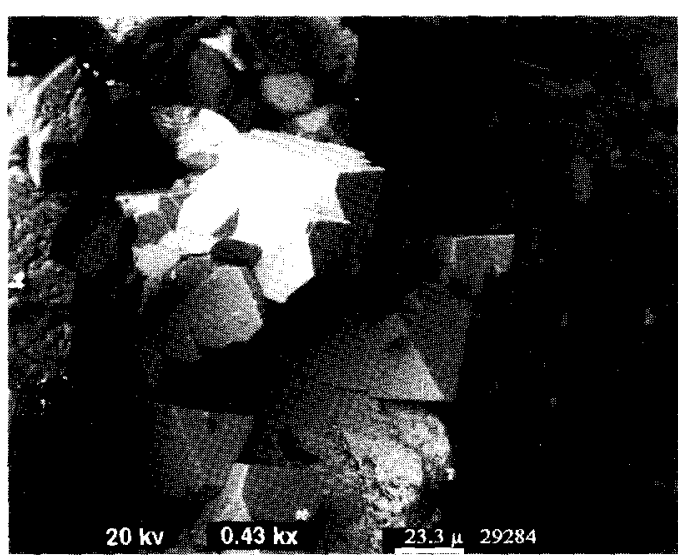

FIc;. 1. SEM photo of mixed jeanbandyite-natanite crystals from Penberthy Croft Mine.

Specimens were collected from two nearby areas on an east-west striking vein exposed in the southern face of the quarry in 1994. The first area contained lustrous pseudo-octahedral crystals of jeanbandyite to $1.2 \mathrm{~mm}$. At a second nearby locality, opaque yellow-brown octahedral crystals to $2 \mathrm{~mm}$ which proved to be jeanbanyite- natanite intergrowths were relatively common. The major primary minerals present at both points in the vein were quartz, arsenopyrite, ferrokesterite and chalcopyrite with cassiterite as "sparable tin" as a minor late-stage primary phase

Jeanbandyite crystallised later than cassiterite in the vein paragenesis, and it is therefore later than all of the major primary minerals. As at Penberthy Croft Mine, its relationship to the minor secondary mineralisation developed in the vein could not be determined, although the presence of a few crystals embedded in arsenopyrite suggests a very late-stage primary origin, from residual tin-rich hydrothermal fluids.

\section{Discussion}

At Llallagua, jeanbandyite occurs as a late-stage primary phase in cavities in high-temperature Sn$\mathrm{W}$-Cu bearing hydrothermal veins where it forms striated, orange-brown, crudely pseudo-octahedral crystals usually less than $0.2 \mathrm{~mm}$ in size. It occurs at Santa Eulalia as an orange-brown overgrowth on natanite crystals up to $0.5 \mathrm{~mm}$. In both cases there is substantial substitution of $\mathrm{Mn}^{2+}$ for iron (Kampf, 1982). Natanite occurs as small greenishbrown crystals in the Sn-bearing veins of the
Trudov and Mushiston deposits where it forms as an alteration product of stannite, and at ChatKaragai as an alteration product of hocartite.

The high-temperature Sn-Cu-As-bearing assemblages at Penberthy Croft Mine and Hingston Downs Quarry closely resemble those at the previously reported localities for jeanbandyite and natanite. In common with these localities, crystallisation is late in the paragenetic scquence, following the major primary phases. It has not been possible to determine with certainty whether the minerals are late-stage primary or supergene in origin, and although the balance of evidence suggests the former (see also Marshukova et al.. 1981. who suggest natanite from central Asia is a late-stage primary phase), we cannot rule out a supergene origin for the Cornish specimens.

Jeanbandyite is assigned to the tetragonal system on the basis of morphology and optics, although $\mathrm{X}$-ray diffraction shows no detectable difference in the a and c lattice parameters $(a=c$ $=7.648 \AA$ ) (Kampf, 1982). Natanite is cubic with $a=7.83 \AA$ in synthetic material and with a range of lower values determined on natural material (e.g. $a=7.79 \AA$ (Kampf, 1982); $a=7.69 \AA$ (Roberts et al., 1990); $a=7.64 \AA$ the lower value quoted on JCPDS: PDF 31-653).

A least squares fit to the $X$-ray data (based on the six most intense diffraction peaks and using silicon as an internal standard) gives a value for the lattice parameter for jeanbandyite from Hingston Downs Quarry of $a=c=7.649(5) \AA$. This is almost identical to the value of $7.648 \AA$. determined on the type material. There is no detectable broadening of the diffraction lines which might indicate slightly differing values of $a$ and $c$. The natanite diffraction pattern, gives a lattice parameter of $a=7.722(8) \AA$ which falls near the centre of the range of values determined for natanite which vary between $7.83 \AA$ in artificial material and $7.64 \AA$ in some natural material.

Three jeanbandyite crystals (not intergrown with natanite) from Hingston Downs Quarry were analysed by electron probe with the results given in Table 1 .

In the original analyses, Kampf (1982) arrived at an empirical formula for jeanbandyite based on six $(\mathrm{OH})$ groups of $\left(\mathrm{Fe}_{0.71}^{31}, \mathrm{Mn}_{0.21}^{2+}, \mathrm{Mg}_{0.04}^{2+}\right)$ $\left(\mathrm{Sn}_{0.84}^{4+}, \mathrm{Si}_{0.03}^{4+}\right)(\mathrm{OH})_{6}$. This has a slight positive excess charge which can be explained if some of the iron is ferrous. Using similar assumptions, we obtain a formula $\left(\mathrm{Fe}_{0.70}^{3+}, \mathrm{Mn}_{0.14}^{2+}, \mathrm{Mg}_{0.03}^{2+}\right)$ 


\section{J. BETTERTONETAL.}

$\left(\mathrm{Sn}_{0.90}^{4-}, \mathrm{Si}_{0.05}^{4-}\right)(\mathrm{OH})_{6}$ for jeanbandyite from Hingston Downs Quarry. Once again there is a slight positive charge imbalance (of 0.24 ), which might be explained if some of the iron is present as $\mathrm{Fe}^{2+}$, or alternatively if silicon was not assigned to the $\mathrm{Si}^{41}$ state. The former assumption produces a formula $\left(\mathrm{Fe}_{0.46}^{3+}, \mathrm{Fe}_{0.24}^{2+}, \mathrm{Mn}_{0.14}^{2+}, \mathrm{Mg}_{0.03}^{2+}\right)$ $\left(\mathrm{Sn}_{0.90}^{4+}, \mathrm{Si}_{0.05}^{4-}\right)(\mathrm{OH})_{6}$. This differs slightly from the ideal stottite group formula, $A^{2+} B^{4-}(\mathrm{OH})_{6}$, in that the presence of trivalent iron must be balanced by vacancies in the crystal structure. However, since microchemical tests on jeanbandyite from Hingston Downs Quarry give a strong positive reaction for $\mathrm{Fe}^{3+}$ and also a definite reaction for $\mathrm{Fe}^{2+}$, it seems likely that the formula is of this type.

Specimens from Hingston Downs Quarry exhibit small compositional differences when compared to the type matcrial. In particular the amount of $\mathrm{Sn}$ is higher in Hingston Downs specimens whereas the $\mathrm{Mn}$ is generally lower and it seems likely therefore that the distribution of lattice vacancics is different. The presence of significant $\mathrm{Mn}^{2+}$ (and $\mathrm{Fe}^{2 r}$ ) in the jeanbandyite analysed here, as well as in the specimens from the type locality suggests an essential role for
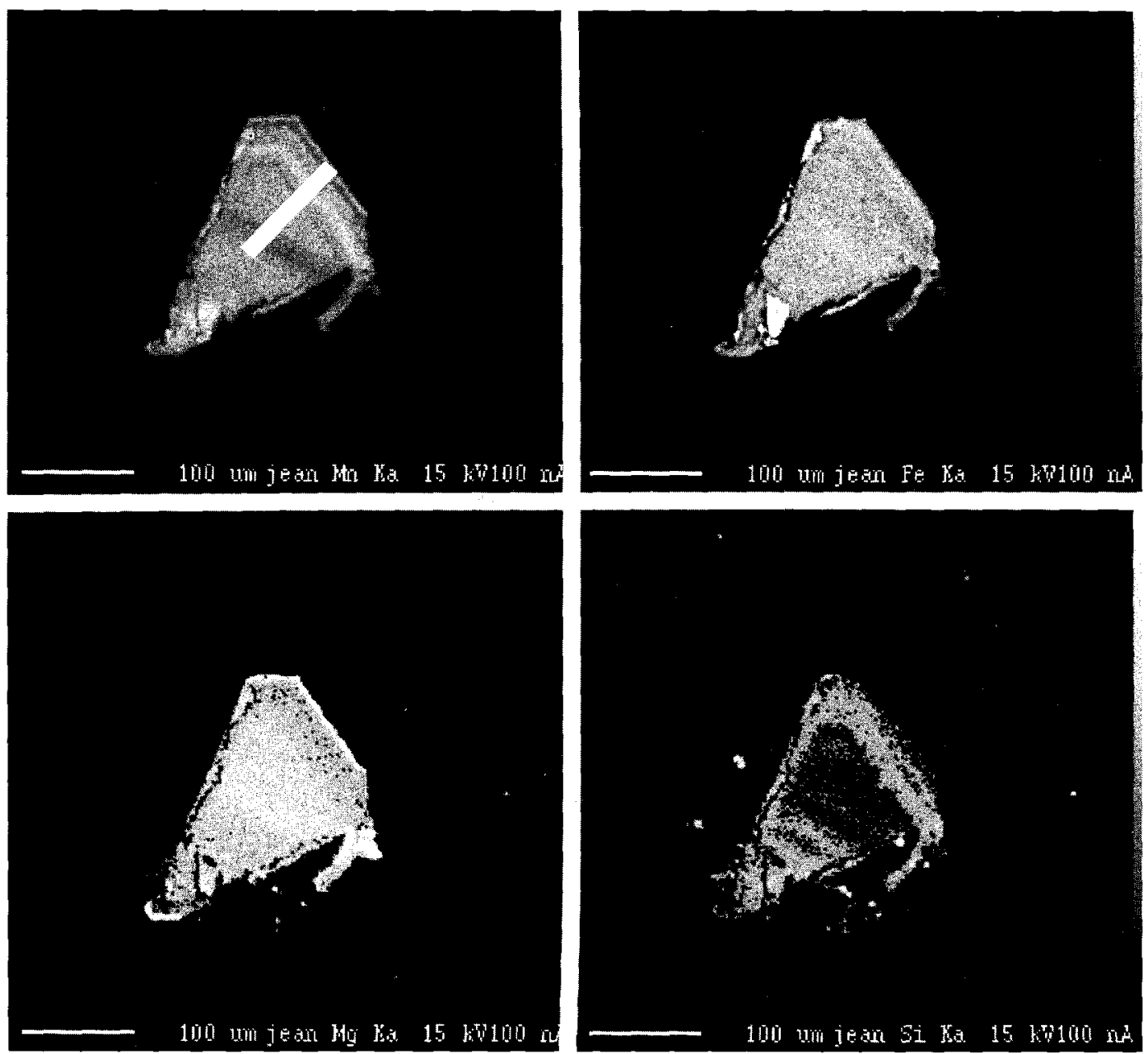

Fic. 2. Element maps for $\mathrm{Mn}, \mathrm{Fe}, \mathrm{Mg}$, and $\mathrm{Si}$, in a single jeanbandyite crystal fragment from Penberthy Croft Mine. The line on the Mn map indicates the traverse along which the spot analyses of Fig. 3 were measured. 
JEANBANDYITE AND NATANITE

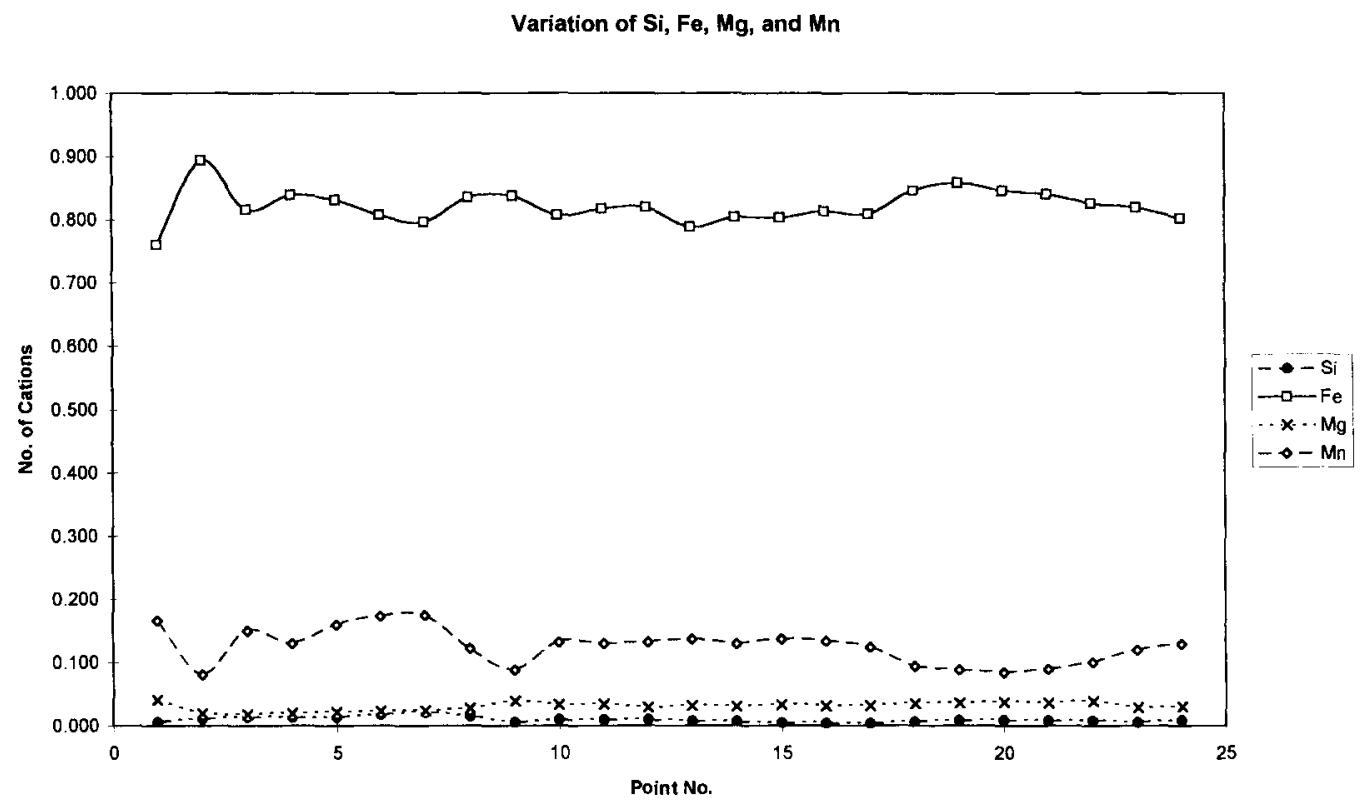

Fli. 3. Graph showing the variations in $\mathrm{Mn}, \mathrm{Fe}, \mathrm{Mg}$, and $\mathrm{Si}$, along the traverse of Fig. 2.

divalent metal ions in the jeanbandyite structure, perhaps to maintain charge balance. Indeed, the formula which is normally quoted, $\left(\mathrm{Fe}_{1-x}^{3+}, \square_{x}\right)\left(\mathrm{Sn}_{1-y}^{4+}, \square_{y}\right)(\mathrm{OH})_{6}$, appears to be an oversimplification, in that no account is taken of the presence of divalent metals. A study of the jeanbandyite structure using single crystal X-ray techniques was initiated to further investigate this, but unfortunately none of the crystal fragments examined thus far have proved suitable.

During electron-probe microanalysis of the mixed jeanbandyite-natanite crystal fragment from Penberthy Croft Mine, distinct chemical zonation was noted, which it was hoped might delineate the two species. The complete crystal was X-ray mapped for $\mathrm{Mn}, \mathrm{Fe}, \mathrm{Si}$, and $\mathrm{Mg}$ and the four maps are shown in Fig. 2. The composition of the crystal was measured at 25 points from its outside edge to the centre in a line shown in Fig. 2. These results are shown graphically in Fig. 3. The manganese map shows growth associated zoning (lighter areas represent an increase in concentration) while the iron map shows similar but inverse zoning such that the sum of iron and manganese remains relatively constant. However, the absence of abrupt changes in crystal chemistry suggests the two minerals are intimately intergrown.
Specimens from Penberthy Croft Mine are preserved at the Natural History Museum, (accession numbers BM 1997,60 and BM 1997,61). Specimens from Hingston Downs Quarry are preserved at The Manchester Museum (accession numbers MANCH:N12926 and N13580 to N13584).

\section{Acknowledgements}

Thanks are due to John Francis of the NHM for $\mathrm{X}$-ray diffraction identifications, to $\mathrm{C}$. Jones (NHM) for assistance with SEM photography and to M. Faulkner of the SEM Unit, Royal Holloway College, University of London for use of analytical facilities. Thanks also to Mike Rothwell for access to specimens and to Dave Plant of the Microprobe Unit at Manchester University for use of the facilities.

\section{References}

Camm, J.S. and Merry, M.G.H. (1991) Bayldonite and its associates from Penberthy Croft Cornwall. $U K J$. Mines Minerals, 9, 6-15.

Kampf, A.R. (1982) Jeanbandyite a new member of the stottite group from Llallagua, Bolivia. Mineral. 


\section{J. BETTERTON ETAL.}

Record, 13, 235-9.

Geier, B.H and Ottemann, J. (1970) New secondary tingermanium and primary tungsten-(molybdenumvanadium-) germanium minerals from the Tsumeb ore deposit. Neues Jahrb. Mineral. Abh., 114. $89-107$.

Grubb, P.L.C. and Hannaford, P. (1966) Magnetism in cassiterite - its source and paragenetic significance as exemplified by a prominent Malayan tin deposit. Mineralium Deposita, 2, 148-71.
Marshukova, N.K., Palovskii, A.B., Sidorenko, G.A. and Chistyakova, N.I. (1981) Vismirnovite, $\mathrm{ZnSn}(\mathrm{OH})_{6}$ and natanite, FeSn $(\mathrm{OH})_{6}$, new tin minerals. Zap. Vses. Mineral. Obshch., 110, 492-500.

Roberts, W.L., Campbell, T.J. and Rapp, G.R. (1990) Encvclopedia of Minerals. Van Nostrand Reinhold.

[Manuscript received 23 October 1997:

revised 23 December 1997] 


\title{
The structure of antimonian dussertite and the role of antimony in oxysalt minerals
}

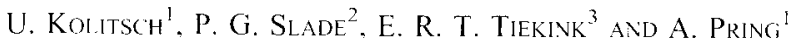 \\ 'Department of Mineralogy, South Australian Museum, North Terrace. Adelaide, S. A. 5000, Australia \\ 2 CSIRO Land and Water. Private Bag No. 2, Glen Osmond, S. A. 5064, Australia \\ 3 Department of Chemistry, The University of Adelaide, Australia 5005
}

\section{ABSTRACT}

The structure of antimonian dussertite, $\mathrm{Ba}\left(\mathrm{Fe}_{0.84}^{3+}, \mathrm{Sb}_{0.16}^{51}\right)_{3}\left(\mathrm{AsO}_{4}\right)_{2}\left(\mathrm{OH}, \mathrm{H}_{2} \mathrm{O}\right)_{6}$, has been refined in space group $R \overline{3} m$ with $a 7.410(3), c 17.484(4) \AA, Z=3$, to $R=3.2 \%$ and $R_{\mathrm{w}}=3.7 \%$ using 377 observed reflections with $I \geqslant 3 \sigma(I)$. The structure is of the alunite-type and consists of sheets of corner-sharing $\left(\mathrm{Fe}^{3-}, \mathrm{Sb}^{5+}\right) \mathrm{O}_{6}$ octahedra parallel to $(0001)$. The substitution of $\mathrm{Sb}^{5+}$ for $\mathrm{Fe}^{3+}$, and not for $\mathrm{As}^{5-}$, is unambiguously demonstrated not only by the structure refinement but also by electron microprobe analyses and crystal-chemical considerations. The icosahedrally coordinated Ba cations occupy cavities between pairs of octahedral shects and are surrounded by six $\mathrm{O}$ atoms from the $\mathrm{AsO}_{4}$ tetrahedra and six $\mathrm{O}$ atoms from the $\left(\mathrm{Fe}^{3 !}, \mathrm{Sb}^{5+}\right) \mathrm{O}_{6}$ octahedra. The mcan bond lengths for the various coordination polyhedra are $\mathrm{As}-\mathrm{O} 1.684(3) \AA$, (Fe, Sb)-O 2.004(1) $\AA$, and Ba-O 2.872(2) $\AA$. A hydrogen-bonding network is modelled using bond-valence calculations. The dussertite sample investigated is the first member of the crandallite group found to contain substantial Sb.

KEYwORDs: dussertite, crystal structure, crystal chemistry, antimony, crandallite group.

\section{Introduction}

As part of a project designed to examine the feasibility of using certain mineral structure types as hosts for the safe and long-term immobilisation of toxic heavy metals such as $\mathrm{Pb}, \mathrm{Tl}, \mathrm{Hg}, \mathrm{As}, \mathrm{Sb}$ and $\mathrm{Cr}$, an evaluation of members of the crandallite (phosphate), beudantite (arsenatesulphate, phosphate-sulphate) and alunite (sulphate) mineral groups has been undertaken. In this context the crystal chemistry and crystallography of these mineral groups is of major interest. Kolitsch and Pring (to be published) have shown that members of these mineral groups can be used, under certain conditions, as stable and reliable hosts for toxic heavy metals.

The present study focuses on the crystal structure and crystal chemistry of antimonian dussertite from the Clara baryte and fluorite mine, Black Forest, Germany. Dussertite, $\mathrm{BaFe}_{3}\left(\mathrm{AsO}_{4}\right)_{2}\left(\mathrm{OH}, \mathrm{H}_{2} \mathrm{O}\right)_{6}$, a rare member of the crandallite group, was originally described from Djebel Debar, Constantine, Algeria, wherc it occurs as minute green crystals flattened $\{0001\}$ and grouped as rosettes or as crusts (Palache et al., 1951). Dussertite belongs to a large family of isostructural compounds with the general formula $A B_{3}\left(X \mathrm{O}_{4}\right)_{2}\left(\mathrm{OH}, \mathrm{H}_{2} \mathrm{O}\right)_{6}$, where $A=$ monovalent $\left(\mathrm{H}_{3} \mathrm{O}, \mathrm{Na}, \mathrm{K}, \mathrm{Ag}, \mathrm{Tl}, \ldots\right)$, divalent (Ca. $\mathrm{Sr}, \mathrm{Ba}, \mathrm{Pb}, \mathrm{Hg}, \ldots$ ), trivalent $(\mathrm{Bi}, R E E)$ or a quadrivalent cation ( $\mathrm{Th}, \mathrm{Zr}$ ), $B=$ trivalent cation (Al, Fe, $\mathrm{Cr}$, ; and minor $\mathrm{Cu}^{2+}, \mathrm{Zn}^{2+}, \mathrm{Nb}^{5 !}, \mathrm{Ta}^{5+}$ ) and $X=\mathrm{P}^{5+}, \mathrm{As}^{5-}, \mathrm{S}^{6+}, \mathrm{Cr}^{6+}$ and minor $\mathrm{Si}$ (Palache et al., 1951; Lottermoser, 1990; Schwab et al., 1990; Lengauer et al., 1994; Fleischer and Mandarino, 1995. 1997). Solid solution among these compounds is cxtensive (e.g. Wise, 1975; Scott, 1987; de Bruiyn et al., 1990; Rattray et al., 1996; Birch and van der Heyden, 1997) and no conclusive evidence for miscibility gaps has yet been found.

The space group of these predominantly rhombohedral compounds is generally $R \overline{3} \mathrm{~m}$; however, other symmetries are known: gorceixite, $\mathrm{BaAl}_{3}\left(\mathrm{PO}_{4}\right)_{2}\left(\mathrm{OH}, \mathrm{H}_{2} \mathrm{O}\right)_{6}$, shows very slight departures from rhombohedral symmetry and crystal-

( 1999 The Mineralogical Societv 


\section{U. KOLITSCHETAL}

lises in space group $\mathrm{Cm}$ (Radoslovich and Slade, 1980; Radoslovich, 1982; Blanchard, 1989); an apparent triclinic dimorph of crandallite, $\mathrm{CaAl}_{3}\left(\mathrm{PO}_{4}\right)_{2}\left(\mathrm{OH}, \mathrm{H}_{2} \mathrm{O}\right)_{6}$, was reported by Cowgill et al. (1963), a specific crystal of beudantite, $\mathrm{PbFe}_{3}\left(\mathrm{AsO}_{4}\right)\left(\mathrm{SO}_{4}\right)\left(\mathrm{OH}, \mathrm{H}_{2} \mathrm{O}\right)_{6}$, was shown by Szymański (1988) to have obvious triclinic symmetry; and a strongly pseudohexagonal orthorhombic jarosite was noted by Jambor and Dutrizac (1983).

For crandallite and, most probably, for woodhouseite, Kato and Radoslovich (1968), Blount (1974) and Kato (1977) found that the divalent $\mathrm{Ca}$ ions are disordered around their sites. Similar disorder for $\mathrm{Pb}$ has also been detected in plumbojarosite (Szymański, 1985), beudantite (Szymański, 1988: Giuseppetti and Tadini, 1989) and kintoreite (Kharisun et al., 1997).

Ordering on the $\mathrm{XO}_{4}$ site has been a matter of some debate. Structure determinations of beudantite, $\mathrm{PbFe}_{3}\left(\mathrm{AsO}_{4}, \mathrm{SO}_{4}\right)\left(\mathrm{OH}, \mathrm{H}_{2} \mathrm{O}\right)_{6}$ (Szymański, 1988: Giuseppetti and Tadini, 1989), and of an arsenatian sulphatian kintoreite, $\mathrm{PbFe}_{3}\left(\mathrm{PO}_{4}, \mathrm{AsO}_{4}, \mathrm{SO}_{4}\right)\left(\mathrm{OH}_{2} \mathrm{H}_{2} \mathrm{O}\right)_{6}$, (Kharisun et al.. 1997), showed that the $\mathrm{XO}_{4}$ anions are disordered and that the space group is $R \overline{3} \mathrm{~m}$. This is at variance with the results of Giuseppetti and Tadini (1987) who reported that $\mathrm{PO}_{4}^{3-}$ and $\mathrm{SO}_{4}^{2-}$ in corkite, $\mathrm{PbFe}_{3}\left(\mathrm{PO}_{4}\right)\left(\mathrm{SO}_{4}\right)\left(\mathrm{OH}, \mathrm{H}_{2} \mathrm{O}\right)_{6}$, are ordered and thus the space group is $R 3 \mathrm{~m}$. A corresponding ordering scheme for $\mathrm{AsO}_{4}^{3--}$ and $\mathrm{SO}_{4}^{2}$ was observed in gallobeudantite (Jambor ef al., 1996).

A large number of the crandallite and beudantite group minerals show anomalous optical behaviour such as biaxial optics (with $2 \mathrm{~V}$ usually between 0 and 20 but in some cases up to 70 ) or biaxial regions in otherwise uniaxial crystals, sector growth, twinning and anomalous interference colours (e.g. Hintze, 1933; Palache et al., 1951; Walenta, 1966; Szymański, 1985). No serious effort has been made so far to explain these anomalies which may indicate that some crystals are not perfectly rhombohedral.

The metal and semi-metal cations in the dussertite structure, $\mathrm{Ba}, \mathrm{Fc}$ and $\mathrm{As}$, are the largest cations that have been observed as major constituents in natural members of the alunite family of compounds. The crystallography and crystal chemistry of dussertite was therefore of special interest. The present contribution describes the previously unknown crystal structure of an antimonian dussertite and discusses the role of $\mathrm{Sb}$ in oxysalt minerals.

\section{Experimental}

The dussertite specimen from which the crystals used in this study came was from the Clara mine, Germany. The specimen consists of unusually sharp, single crystals up to $0.3 \mathrm{~mm}$, scattered on a goethite-covered matrix of corroded baryte. The yellowish to olive-green, transparent crystals are consistently composed of lustrous positive $\{10 \overline{1} 2\}$ and negative $\{01 \overline{1} 2\}$ rhombohedra of almost equal size, with the top of each crystal capped by a small, triangular basal face $\{0001\}$ of matt appearance. The dussertite apparently was formed by the interaction of arsenate- and iron-rich solutions with the baryte gangue. A similar genesis has been reported for the $\mathrm{Al}$ analoue of dussertite, arsenogorceixite $\left(\mathrm{BaAl}_{3}\left(\mathrm{AsO}_{4}\right)_{2}\right.$ $\left(\mathrm{OH}, \mathrm{H}_{2} \mathrm{O}\right)_{6} ;$ Walenta, 1966).

A preliminary investigation of the chemical composition of several crystals from the sample was done by energy-dispersive X-ray spectroscopy (EDS) in a scanning electron microscope (SEM). The analyses showed the crystals to contain significant amounts of Sb. For quantitative analysis by wavelength-dispersive X-ray spectroscopy, a Cameca 'Camebax 51' electron microprobe was used. These measurements, conducted on polished and carbon-coated crystals, were supplemented by qualitative EDS. The crystals proved to be stable under the electron beam as shown by the use of different beam diameters. Besides the major cations $\mathrm{Ba}, \mathrm{Fe}$ and $\mathrm{As}$, a considerable amount of $\mathrm{Sb}$ was confirmed, but the absolute $\mathrm{Sb}$ content was slightly variable. The $\mathrm{Fe} / \mathrm{Sb}$ ratio was 5.4 (average of 6 analyses. range: $2.8-6.5$ ). Contrast-enhanced backscattered electron images were unable to distinguish any chemical inhomogeneities. The following elements were detected in very small to trace amounts (in order of decreasing abundance): $\mathrm{Sr}$, F, Al, Si, P, Cu, Si, K, Ca. Flements searched for but not detected were $\mathrm{Pb}, \mathrm{Ce}$ and $\mathrm{Bi}$. An idealised cmpirical formula $\mathrm{Ba}_{0.9}\left(\mathrm{Fe}_{0.84}^{3-}, \mathrm{Sb}_{0.16}^{5+}\right)_{2.6}\left(\mathrm{AsO}_{4}\right)_{2}$ $\left(\mathrm{OH}, \mathrm{H}_{2} \mathrm{O}\right)_{6}$ was calculated on the basis of 2 $\mathrm{XO}_{4}$, as recommended by Scott (1987). Vacancies were assumed not to be present. The assignment of $\mathrm{Sb}$ to the $\mathrm{Fe}$ site was supported by the results of the structure refinement (sec below).

To investigate any possible deviation from uniaxial behaviour, the optical properties were carefully determined on grain mounts in white light, using Cargille immersion liquids. The grains were found to be uniaxial negative, slightly pleochroic, O greenish yellow, E pale yellow to 
colourless, \& $1.840 \pm 0.005$, (1) $1.865 \pm 0.005$. The refractive indices are close to those reported previously (1.85, 1.87, Barth and Berman, 1930; $1.845,1.870$, Foshag. $1937 ; \sim 1.87$ with rather low bircfringence, Walenta, 1966). The dussertite crystals investigated by Foshag (1937) were reported to be uniaxial to abnormally biaxial with $2 \mathrm{~V}=15-20$. No such biaxial optics were noticed in the present study. However, slightly anomalous, bluish-grey to bluish interference colours were observed throughout. Unlike the dussertite of Walenta (1966), for some of which a more or less pronounced sector growth was reported, no such anomaly was observed during the present study. Rarely, some crystal fragments exhibit very faint striation growth features parallel to the crystal faces. No evidence of twinning was found. For comparison, and to evaluate possible effects of the high $\mathrm{Sb}$ content, an olive-green dussertite specimen from the type locality in Algeria was also investigated optically. It is uniaxial negative (or biaxial with a very small optical angle) and shows the same anomalous bluish interference colours. A semiquantitative analysis revealed only $\mathrm{Ba}$, Fe and $\mathrm{As}$, along with traces of $\mathrm{Cu}$. and confirmed this specimen to have an almost end-member composition. Therefore, the presence of $\mathrm{Sb}$ docs not influence the optical properties in an obvious way.

Several single crystals were removed from the sample and, after being checked with a polarising microscope, two were selected for investigation by Weissenberg and precession methods. The diffraction pattems did not reveal any deviation from thombohedral symmetry and enabled the space group to be determined as $R 32, R 3 m$ or $R 3 \mathrm{~m}$. The crystal showing the sharpest reflections was mounted on a Rigaku AFC6R rotating anode four-circle single-crystal diffractometer. Unit cell dimensions, refined from 11 reflections $(2 \theta=53.9-54.8)$, are $a=7.410(3)$ and $c=17.484(4) \AA$. Intensity data were measured at room temperalure using graphite monochromatised Mo- $K x$ radiation and the $(0)-20$ scan technique for a full sphere of reciprocal space such that $0_{\text {max }}=$ 32.5 (Table 1). A total of 2157 reflections representing 409 unique reflections were measured. out of which 32 with $l<3 \sigma(I)$ were considered unobserved and excluded from the refinement. The data were corrected for Lorentz. and polarisation effects, for anomalous dispersion. and an analytical absorption correction, based on the crystal size and faces, was applied (dc Meulenaer and Tompa, 1965). Normalised structure-factor statistics clearly indicated the centrosymmetric space group $R \overline{3} \mathrm{~m}$. As input values for the atomic positions of $\mathrm{Ba}, \mathrm{Fc}$, $A s$ and $O$, the data reported for kintoreite (Kharisun et al., 1997) were used. Scattering factors for neutral atoms were taken from the International Tables for X-ray Crystallography (1974). After the refinement of the scale factor and positional and isotropic displacement parameters, $R$ was $7.3 \%$, and a large, positive residual electron density remained on the Fe site but not on the As site. Therefore, and on account of crystalchemical considerations (see discussion). Sb was allocated to the $\mathrm{Fe}$ site. After introducing anisotropic displacement parameters for $\mathrm{Ba}$ $(\mathrm{Fe}, \mathrm{Sb})$ and $\mathrm{As}$, and constraining the displacement parameters for $\mathrm{Sb}$ and $\mathrm{Fe}$, the intensity data were merged and $R$ dropped to $3.8 \%$. The displacement parameters were then held constant and the individual occupancies of $\mathrm{Fe}$ and $\mathrm{Sb}$ on their common site were adjusted. A further drop of $R$ to $3.3 \%$ resulted and the $\mathrm{Fe} / \mathrm{Sb}$ ratio obtained was $0.84(2) / 0.16(2)$. At convergence, $R=3.2 \%$ and $R_{W}=3.7 \%$. The final electron density map was relatively flat, with the maximum value $\left(1.3 \mathrm{e} / \AA^{3}\right)$ near the position of $O(3)$. Hydrogen atoms could not be located unambiguously. All computations were carried out with version 1.6 of the teXsan suite of computer programs (Molecular Structure Corporation, 1993). Bond-valence calculations using the program EUTAX (O'Keeffe, 1991; Brese and O'Keeffe, 1991) helped to model the hydrogen-bonding network and establish the crystal-chemical reliability of the structure refinement.

\section{Results and discussion}

The final atomic coordinates and displacement parameters for the structure are listed in Table 2 and selected interatomic distances and bond angles are given in Table 3. A summary of the bond-valence calculations for the structure is provided in Table 4, and a full list of observed and calculated structure factors for the final refinement are given in Table 5 (deposited with the Editor).

The crystal structure of dussertite is similar to that of crandallite (Blount, 1974) and closely related to the structures of the beudantite and alunite groups. The individual metal-oxygen polyhedra are shown in Figs. 1-3.

Calculated bond-valence sums (BVSs) suggest that both $O(1)$ and $O(3)$ are bonded to hydrogens, at least partly (Table 4). In other crandallite-type 


\section{U. KOLITSCHETAL.}

TABLE 1. Crystal data, data collection information and refinement details for antimonian dussertite

\begin{tabular}{|c|c|}
\hline \multicolumn{2}{|l|}{ Crystal data: } \\
\hline Formula & $\mathrm{Ba}\left(\mathrm{Fe}_{0.84} \cdot \mathrm{Sb}_{0.16}\right)_{3}\left(\mathrm{AsO}_{4}\right)_{2}\left(\mathrm{OH}, \mathrm{H}_{2} \mathrm{O}\right)_{6}$ \\
\hline Formula weight & 716.43 \\
\hline Crystal system & Rhombohedral \\
\hline Space group & $R \overline{3} m$ \\
\hline$a, c(\AA)$ & $7.410(3), 17.484(4)$ \\
\hline$V\left(\AA^{3}\right), Z$ & $831.3(3), 3$ \\
\hline$D$ (calc. $)\left(\mathrm{g} / \mathrm{cm}^{3}\right)$ & 4.293 \\
\hline$F(000)$ & 990 \\
\hline$\mu\left(\mathrm{cm}^{\mathrm{I}}\right)$ & 138.9 \\
\hline Absorption correction & analytical \\
\hline Transinission factors & $0.093-0.246$ \\
\hline Crystal dimensions (mm) & $0.16 \times 0.16 \times 0.16$ \\
\hline \multicolumn{2}{|l|}{ Data Collection: } \\
\hline Diffractometer & Rigaku AFC6R (rotating anode) \\
\hline Scan mode & $(0)-2 \theta$ \\
\hline Temperature $(\mathrm{K})$ & 293 \\
\hline$\lambda\left(M_{0}-K \alpha\right)(\AA)$ & 0.71073 \\
\hline$\theta$ range () & $3-32.5$ \\
\hline$h, k, /$ ranges & $-11 \rightarrow 11,-11 \rightarrow 11,-26 \rightarrow 26$ \\
\hline Total reflections measured & 2157 \\
\hline Unique reflections & 409 \\
\hline \multicolumn{2}{|l|}{ Refinement: } \\
\hline Refinement on & $F$ \\
\hline Weighting scheme & $1 /\left[\sigma^{2}\left(F_{0}\right)+\left(0.019 F_{0}\right)^{2}\right]$ \\
\hline$R, R_{\mathrm{W}}$ & $3.2 \%, 3.7 \%$ \\
\hline Refls. used in refinement & $377(I \geqslant 3 \sigma(I))$ \\
\hline No. of refinable parameters & 18 \\
\hline$(\Delta / \sigma)_{\max }$ & 0.0022 \\
\hline$\left.\Delta \rho_{\text {min }}, \Delta \rho_{\text {max }}\left(\mathrm{e} / \AA^{3}\right)^{3}\right)$ & $-1.1,1.3$ \\
\hline
\end{tabular}

TABLE 2. Fractional atomic coordinates and displacement parameters for antimonian dussertite (s.u.s in parentheses)

\begin{tabular}{|c|c|c|c|c|c|c|c|}
\hline Atom & $\mathrm{x}$ & $y$ & z & & $U_{\mathrm{cq}}$ & \multicolumn{2}{|c|}{ Occupancy } \\
\hline $\mathrm{Ba}$ & 0.0 & 0.0 & 0.0 & & $0.0155(1)$ & & \\
\hline $\mathrm{Fe}$ & 0.5 & 0.0 & 0.5 & & $0.0136(1)$ & & \\
\hline $\mathrm{Sb}$ & 0.5 & 0.0 & 0.5 & & $0.0136(1)$ & & \\
\hline As & 0.0 & 0.0 & $0.31047(7)$ & & $0.0127(1)$ & & \\
\hline$O(1)$ & 0.0 & 0.0 & $0.5929(5)$ & & $0.018(2)$ & & \\
\hline$O(2)$ & $0.2099(4)$ & $-x$ & $-0.0554(3)$ & & $0.0145(8)$ & & \\
\hline \multirow[t]{2}{*}{$\mathrm{O}(3)$} & $0.1260(4)$ & $-x$ & $0.1366(2)$ & & $0.0131(8)$ & & \\
\hline & $U_{11}$ & $U_{22}$ & $U_{33}$ & $U_{12}$ & & $U_{13}$ & $U_{23}$ \\
\hline $\mathrm{Ba}$ & $0.0148(3)$ & $U_{11}$ & $0.0171(4)$ & $0.5 U_{11}$ & & 0.0 & 0.0 \\
\hline $\mathrm{Fe} / \mathrm{Sb}$ & $0.0124(4)$ & $0.0094(7)$ & $0.0184(5)$ & $0.5 U_{22}$ & & $0.0003(2)$ & $2 U_{13}$ \\
\hline As & $0.0101(3)$ & $U_{11}$ & $0.0179(5)$ & $0.5 U_{\mathrm{ll}}$ & & 0.0 & 0.0 \\
\hline
\end{tabular}


STRUCTURE OF ANTIMONIAN DUSSERTITE

TABLE 3. Interatomic distances $(\AA)$ and bond angles ( ) for the coordination polyhedra in antimonian dussertite

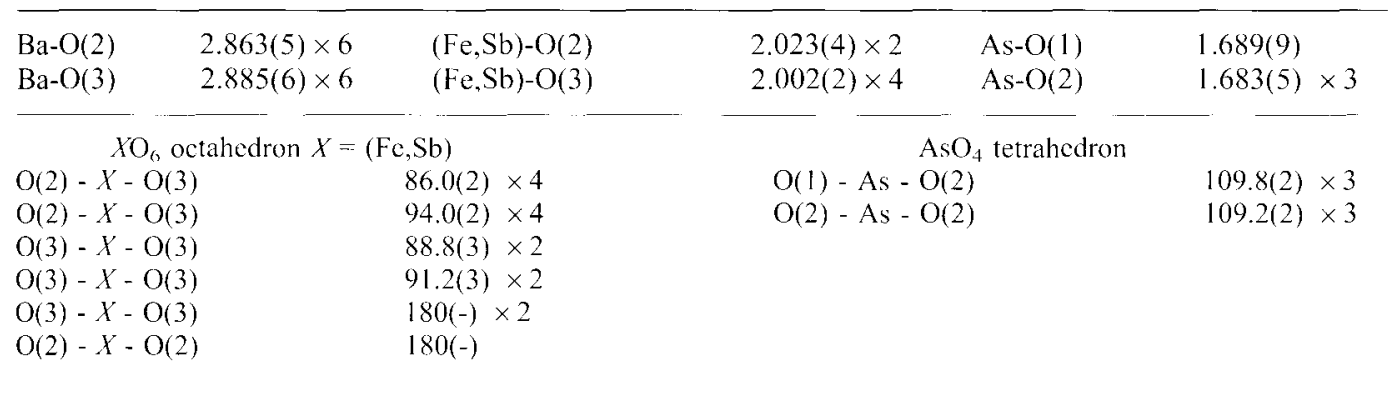

structures, $O(3)$ is generally considered to be a hydroxyl and $O(1)$ half of a hydroxyl (e.g. crandallite, kintoreite). Thus, hydrogen bonds can be postulated for only three of the six $O(1)-O(3)$ contacts (contact lengths $3 \times 2.88 \AA$ ) but not for the $O(1)-O(1)$ contacts $(3.25 \AA)$, the $\mathrm{O}(1)-\mathrm{O}(2)$ contact $(2.76 \AA)$, or for two of the four $O(2)-O(3)$ contacts $(2 \times 2.74 \AA)$. These hydrogen bonds must be both weak and bent since the $O(1)-O(3)$ bond distances are large compared to the average distance $\mathrm{O} \cdots \mathrm{O}$ of the hydrogen bond in monoprotonated arsenate groups $(2.61 \AA$, Ferraris and lvaldi, 1984).

If $O(3)$ is a donor, the BVSs calculated with the inclusion of the estimated hydrogen-bonding contributions according to Brown and Altermatt (1985) would give $-2.10 \mathrm{~m}$ (valence units) and $\sim 1.39 v u$ for $O(3)$ and $O(1)$, respectively. This

TABLF 4. Results of empirical bond-valence calculations for antimonian dussertite

\begin{tabular}{|c|c|c|c|c|}
\hline & $\mathrm{Ba}$ & $\mathrm{Fe}, \mathrm{Sb}$ & As & Sum \\
\hline$O(1)$ & & & 1.23 & $1.23 \#(\sim 1.39)^{*}$ \\
\hline$O(2)$ & $\begin{array}{l}0.21 \\
(\times 6)\end{array}$ & $\begin{array}{l}0.54 \\
(\times 2)\end{array}$ & $\begin{array}{l}1.25 \\
(\times 3)\end{array}$ & $2.00 \#$ \\
\hline$O(3)$ & $\begin{array}{l}0.20 \\
(\times 6)\end{array}$ & $\begin{array}{l}0.57 \times 2 \\
(\times 4)\end{array}$ & & $1.34 \#(\sim 2.10) *$ \\
\hline Sum & 2.46 & $3.36 \#$ & 4.98 & \\
\hline
\end{tabular}

\# The sum values for $\mathrm{O}(1,2,3)$ and $(\mathrm{Fe}, \mathrm{Sb})$ correspond to the refined occupancy of the $(\mathrm{Fe}, \mathrm{Sb})$ site. Calculations for $\mathrm{Fe}^{31}$ alone gave $3.05 \mathrm{vu}$ and for $\mathrm{Sb}^{5}$ alone $5.01 \mathrm{vu}$. The sum value of $3.36 v u$ reflects the increased average valency.

* Values in parentheses are obtained after adding the $\mathrm{H}$ bond contributions (see text). would agrec with the observation that about half of the $O(1)$ atoms are protonated. Stereochemical considerations also suggest $O(3)$ represents the donor, as it is the only $\mathrm{O}$ coordinated to $\mathrm{Ba}$ and ( $\mathrm{Fe}, \mathrm{Sb}$ ) but not $\mathrm{As}$, and the $\mathrm{Fe}-\mathrm{O}(3)$ distances are slightly shorter than the Fe-O(2) distances (2.002(2) w $2.023(2) \AA)$. If $\mathrm{O}(1)$ were a donor, it would represent the hydroxyl in a monoprotonated arsenate group and the $\mathrm{As}-\mathrm{O}(\mathrm{H})$ distance would be expected to be smaller than the three other As-O distances (Ferraris and Ivaldi, 1984). This is clearly not the case (Table 3 ). Nonetheless, our data are not sufficient to exclude any positional disorder of the hydrogen.

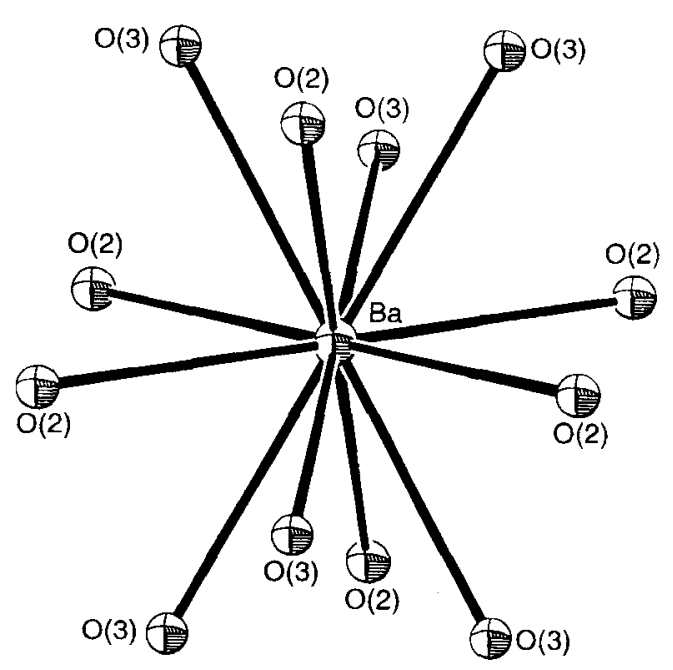

Fici, 1. The unusually regular, icosahedral $\mathrm{BaO}_{12}$ polyhedron in the structure of antimonian dussertite. Thermal ellipsoids are drawn at the $50 \%$ probability level. 


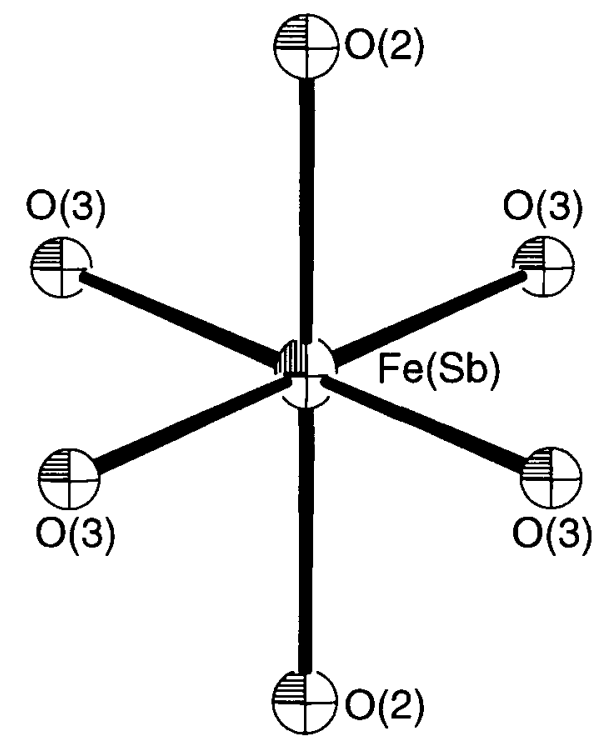

Fici. 2. The almost regular $(\mathrm{Fe}, \mathrm{Sb}) \mathrm{O}_{6}$ octahedron. Thermal cllipsoids are drawn at the $50 \%$ probability level.

The BVS value obtained for Ba, $2.46 \mathrm{l} u$, is unsatisfactory. However, it is known that Ba compounds in general tend to give poor BVSs (Brown and $\mathrm{Wu}, 1976$ ). Ba is coordinated to six $O(2)$ and six $O(3)$ (with similar bond lengths. $2.863(5)$ and $2.885(6) \AA$ ) to form an unusually regular, ball-shaped icosahedron (Fig. 1). Therefore, a minor change in the Ba-O distance would influence the BVS to a large extent. The very minor $\mathrm{Sr}$ content of the crystal would be expected to result in only a very small decrease of the BVS. The average Ba-O bond lengths are slightly larger than the range of $2.834-2.860 \AA$ determined for the $\mathrm{Ba}$-Al-phosphate member of the crandallite group, gorceixite (Radoslovich. 1982) but smaller than the average $\mathrm{Ba}-\mathrm{O}$ bond length in jagowerite, $\mathrm{BaAl}_{2}\left(\mathrm{PO}_{4}\right)_{2}(\mathrm{OHI})_{2}$. (2.965 A; Meagher et al., 1974) or in baryle (2.95 A, range 2.76-3.30 A; Hill, 1977, Baur, 1981). No comparable data are available for arsenogorceixitc, the other $\mathrm{Ba}$ arsenate endmember of the crandallite group.

In contrast to the disorder of the $\mathrm{Ca}$ site observed and suggested for crandallite and woodhouscite, respectively (Kato and

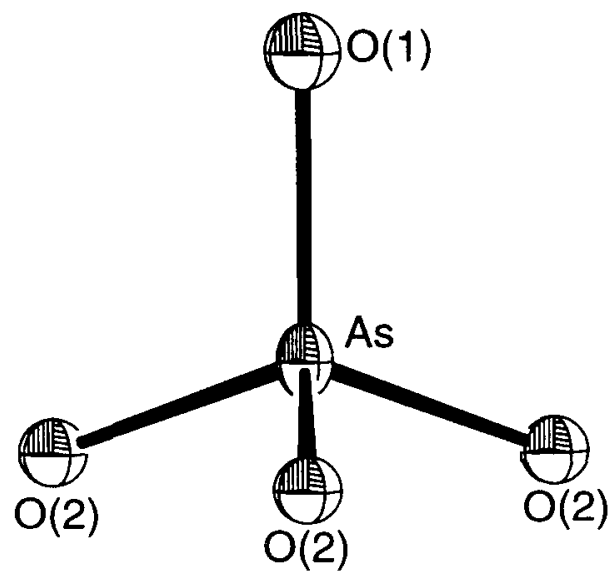

Fici. 3. The $\mathrm{AsO}_{4}$ tetrahedron, showing the experimentally equivalent As-O bond lengths. Thermal ellipsoids are drawn at the $50 \%$ probability level.

Radoslovich, 1968: Blount, 1974; Kato, 1977), no disorder, or anomalously large displacement factors, for the Ba site were observed for dussertite (cf. Table 2). This is not unexpected because $\mathrm{Ba}$, being larger than $\mathrm{Ca}$, would more easily fit into the $A$ cation 'cagc'. The situation in dussertite is also quite different from that in $\mathrm{Pb}$ members of the crandallite and beudantite groups, all of which exhibit highly variable $\mathrm{Pb}-\mathrm{O}$ bond lengths and displacement and disordering phenomena due to the influence of the lone electron pair of $\mathrm{Pb}^{2}$

As pointed out above, both the refinement and the electron microprobe analyses clearly indicate that Sb partly occupies the Fe site but not the As site. The $\mathrm{Fe} / \mathrm{Sb}$ ratio in the formula suggested by the refinement, $\mathrm{Ba}\left(\mathrm{Fc}_{0.44}^{3}, \mathrm{Sb}_{0}^{5+16}\right)_{3}\left(\mathrm{AsO}_{4}\right)_{2}$ $\left(\mathrm{OH}, \mathrm{H}_{2} \mathrm{O}\right)_{6}$, is in good agreement with the result from the electron microprobe analysis. Previously, Sb detected in crandallite- and beudantite-group minerals has been assumed to substitute for As (e.g. Smith et al., 1953; Martin ef al., 1994). The disordered character of the Sb-Fe substitution can be compared to the situation in a $\mathrm{Pb}$-sulphate member of the alunite group, osarizawaite, in which the $B$ site in the structure is occupicd by disordered $\mathrm{Al}^{31}, \mathrm{Fe}^{3 .}$ and $\mathrm{Cu}^{2}$ (Giuseppetti and Tadini, 1980).

The valency of $\mathrm{Sb}$ was assumed to be $5+$ because dussertite crystallised in an oxidising environment and because of the strong prevalence of pentavalent $\mathrm{Sb}$ in comparable secondary $\mathrm{Sb}$ 


\section{STRUCTURE OF ANTIMONIAN DUSSERTITE}

minerals (see more detailed discussion below). The nominal ionic radius of ${ }^{[\vee 1 \mid} \mathrm{Fe}^{31}, 0.645 \AA$, is similar to that of ${ }^{[\mathrm{VI}]} \mathrm{Sb}^{5+}, 0.60 \AA$ (Shannon, 1976), whereas the radius of ${ }^{\left[V^{I}\right]} \mathrm{Sb}^{3+}$ is $0.76 \AA$. The $\mathrm{Sb}^{51}$ ion would not be accommodated casily into the four-coordinate $\mathrm{As}{ }^{5+}$ site as the radius of ${ }^{\left[{ }^{1 V}\right]} \mathrm{As}^{5-}$ is only $0.335 \AA$. The average coordination number of $\mathrm{Sb}^{5+}$ in inorganic compounds is 6.05 , and those of $\mathrm{Fe}^{3+}$ and $\mathrm{As}^{5+}$ are 5.69 and 4.41, respectively (Brown, 1988). These data provide further support that $\mathrm{Sb}^{5-}$ enters the sixcoordinate $\mathrm{Fe}^{3+}$ site in preference to the fourcoordinate $\mathrm{As}^{51}$ site.

The $(\mathrm{Fe}, \mathrm{Sb}) \mathrm{O}_{6}$ octahedron is only slightly distorted (Fig. 2), and its symmetry and average (Fe,Sb)-O bond length, 2.004(1) $\AA$, are similar to those of the $\mathrm{FeO}_{6}$ octahedra in kintoreite (2.011 $\AA$, Kharisun et al., 1997) and plumbojarosite (2.008 A. Szymanski, 1985), whereas in aluminian beudantite, as expected, this value is slightly lower (1.997 A, Szymański, 1988). Bondvalence calculations for the $(\mathrm{Fe}, \mathrm{Sb})$-site in dussertite were conducted assuming $100 \%$ occupancy of this site by each of the cations. For $\mathrm{Fe}^{3+}$ a value of $3.05 \mathrm{v} u$ was calculated, and the result for $\mathrm{Sb}^{5+}$ was $5.01 \mathrm{v} u$. The BVS given in Table 4, $3.36 \mathrm{v}$, was taken to be the weighted mean of those values on the basis of the refined composition, and reflects the increased average valency. The value for $\mathrm{Sb}^{5-}, 5.01 \mathrm{vm}$, is in very good agreement with the proposed $\mathrm{Sb}$ valency, and suggests that $\mathrm{Fe}-\mathrm{Sb}$ substitution may be extensive.

The charge imbalance induced by the substitution of $\mathrm{Sb}^{51}$ for $\mathrm{Fe}^{3 !}$ amounts to 0.96 additional positive charges, which can be accounted for in two ways: firstly, a small percentage of the (idcally) four hydroxyls surrounding the $(\mathrm{Fe}, \mathrm{Sb})$ site may lose their hydrogens and so increase the net negative charge of the anions in the $(\mathrm{Fe}, \mathrm{Sb})(\mathrm{OH})_{4} \mathrm{O}_{2}$ octahedron; secondly, there might be vacancies on the $(\mathrm{Fe}, \mathrm{Sb})$ site. The total $(\mathrm{Fe}+\mathrm{Sb})$ content obtained by the microprobe analysis corresponds to 8.6 positive charges (neglecting the very minor amounts of $\mathrm{Al}$ ) and could suggest the presence of vacancies. However, the estimated accuracy of the chemical analysis does not allow a definite conclusion to be drawn. No residual negative electron densities on the $(\mathrm{Fe}, \mathrm{Sb})$ site and the small anisotropic displacement factors indicate that this sitc is fully occupied. The modelled hydrogen-bonding network, and especially the unusually regular $\mathrm{BaO}_{12}, \mathrm{AsO}_{4}$ and $(\mathrm{Fe}, \mathrm{Sb}) \mathrm{O}_{6}$ polyhedra, support the first assumption, i.e. that fewcr hydroxyls are present in antimonian dussertite than might be expected for dussertite itself.

\section{The role of antimony in other minerals}

Other minerals in which $\mathrm{Sb}^{51}$ shares the same site with $\mathrm{Fe}^{31}$ include örebroite, $\mathrm{Mn}_{3}^{2-}\left(\mathrm{Sb}^{5+}, \mathrm{Fe}^{3+}\right)$ $\mathrm{Si}(\mathrm{O}, \mathrm{OH})_{7}$, bismutostibiconite, $\mathrm{Bi}\left(\mathrm{Sb}^{5-}, \mathrm{Fe}^{31}\right)_{2} \mathrm{O}_{7}$, and melanostibite, $\mathrm{Mn}\left(\mathrm{Sb}^{5}, \mathrm{Fe}^{3+}\right) \mathrm{O}_{3}$ (all formulae here and hereafter according to Fleischer and Mandarino, 1995, 1997). In the above three compounds, $\mathrm{Sb}$ exceeds Fe, unlike the situation in antimonian dussertite. Apparent ordering of $\mathrm{Sb}^{5+}$ and $\mathrm{Fe}^{3 \cdot}$ over their octahedrally coordinated sites is known only from the mineral filipstadite, $\left(\mathrm{Mn}^{2+}, \mathrm{Mg}\right)_{4} \mathrm{Sb}^{5+} \mathrm{Fe}^{3-} \mathrm{O}_{8}$ (Dunn et al., 1988). On the other hand, $\mathrm{Sb}^{3-}$ and $\mathrm{Fe}^{31}$ do not secm to substitute for each other, as indicated by the minerals chapmanite $\mathrm{Sb}^{3} \mathrm{Fe}_{2}^{3-}\left(\mathrm{SiO}_{4}\right)_{2}(\mathrm{OH})$ and derbylite, $\left(\mathrm{Fe}^{3-}, \mathrm{Fe}^{2+}, \mathrm{Ti}_{7}\right)_{7} \mathrm{Sb}^{3+} \mathrm{O}_{13}(\mathrm{OH})$.

To our knowledge, trivalent $\mathrm{Sb}$ in secondary minerals formed by supergene processes, in strongly oxidising environments, has not been described yet. Examples of secondary minerals containing pentavalent $\mathrm{Sb}$ include camerolaite, $\mathrm{Cu}_{4}^{21} \mathrm{Al}_{2}\left(\mathrm{HSb}^{5} \mathrm{O}_{4}, \mathrm{SO}_{4}\right)\left(\mathrm{CO}_{3}\right)(\mathrm{OH})_{10} \cdot 2 \mathrm{H}_{2} \mathrm{O}$, cualstibite, $\mathrm{Cu}_{6}^{2+} \mathrm{Al}_{2} \mathrm{Sb}_{3}^{5-} \mathrm{O}_{18} \cdot 16 \mathrm{H}_{2} \mathrm{O}$, mammothite, $\mathrm{Pb}_{6} \mathrm{Cu}_{4}^{2+} \mathrm{AlSb}^{5-}\left(\mathrm{SO}_{4}\right)_{2} \mathrm{Cl}_{4} \mathrm{O}_{2}(\mathrm{OH})_{16}$, brizziitc, $\mathrm{NaSb}^{5+} \mathrm{O}_{3}$, and bottinoite, $\mathrm{NiSb}^{51}(\mathrm{OH})_{12} \cdot 6 \mathrm{H}_{2} \mathrm{O}$.

In minerals containing both $\mathrm{Sb}^{5+}$ and $\mathrm{As}^{5-}$, such as richelsdorfite, $\mathrm{Ca}_{2} \mathrm{Cu}_{5}^{2} \mathrm{Sb}^{5-}\left[\mathrm{Cl}(\mathrm{OH})_{6}\right.$, $\left.\left(\mathrm{AsO}_{4}\right)_{4}\right] \cdot 6 \mathrm{H}_{2} \mathrm{O}$ (Süsse and Tillmann, 1987) and $\mathrm{Pb}_{3} \mathrm{Sb}^{5-}(\mathrm{OH})_{6}\left(\mathrm{SO}_{4}\right)\left(\mathrm{AsO}_{4}\right) \cdot 3 \mathrm{H}_{2} \mathrm{O}$ (the Sb-dominant analogue of fleischerite; Sima et al., 1996; Mandarino and Grice, 1997), these cations occupy different sites. There seem to be only two examples of supergene minerals in which $\mathrm{Sb}^{51}$ possibly substitutes for $\mathrm{As}^{5-}$ : sabelliite, $(\mathrm{Cu}, \mathrm{Zn})_{2} \mathrm{Zn}\left[\left(\mathrm{As}^{5+}, \mathrm{Sb}^{5+}\right) \mathrm{O}_{4}\right](\mathrm{OH})_{3} \quad(\mathrm{Olmi}$ et al. $1995)$ and theisite, $\mathrm{Cu}_{5}^{2} \mathrm{Zn}_{5}\left[(\mathrm{OH})_{7}\right.$ $\left.\left(\mathrm{As}^{5} \cdot \mathrm{Sb}^{5+}\right) \mathrm{O}_{4}\right]_{2}$. The structure of theisite has not been determined and thus the proposed structural formula may not be correct. In the structure of sabelliite, whose refinement presented some inconsistencies (Olmi et al., 1995), there are threc As sites, one of which is reported to be partially occupied by disordered $\mathrm{Sb}$ and $\mathrm{As}$ and surrounded by four $\mathrm{O}$ atoms, forming a trigonal pyramid.

In dussscrtite, the As atom forms a highly regular $\mathrm{AsO}_{4}$ tetrahedron (Fig. 3) and the average As-O bond length, 1.684(3) $\AA$, is almost identical to the values reported for the average arsenate 
tetrahedron in arsenates $(1.683 \AA$, Shannon and Calvo, 1973; $1.682 \AA$, Baur; 1981). If $\mathrm{As}^{5+}$ had been replaced by the much larger $\mathrm{Sb}^{5-}$, then an appreciably increased bond length would have been observed, probably accompanied by a distortion of the tetrahedron.

The As-O(1) bond is not shorter than the three As-O(2) bonds and indicates that $O(1)$ is not protonated. This contrasts with the analogous bonds in most other members of the alunite family. In them, half of $\mathrm{O}(1)$ of the $X-\mathrm{O}(1)$ bond pair is reported to be a hydroxyl, with the $X-\mathrm{O}(1)$ bond therefore being shorter. The 'missing' hydrogen in dussertite is consistent with the proposed charge balance for the Sb-Fe substitution.

The unit cell volume, $V=831.3(3) \AA^{3}$. is slightly smaller than the value reported for an unanalysed but probably quite pure dussertite sample from the type locality $\left(V=835.1(1) \AA^{3}\right.$, JCPDS-PDF 35-621). The lower values may reflect the very minor $\mathrm{Sr}$ and $\mathrm{Al}$ contents in the investigated crystal and/or the ionic radius of ${ }^{[\mathrm{VI}]} \mathrm{Sb}^{51}$ being slightly smaller than that of ${ }^{[\mathrm{VI}]} \mathrm{Fe}^{3-}$ $(0.60$ v $0.645 \AA)$.

\section{Suggestions for future work}

The currently available data on crystal structures of the crandallite and beudantite and alunite groups demonstrate that it would be desirable to apply neutron diffraction methods to obtain more accurate data on the hydrogen positions and their influence on the symmetry. It may also prove useful to investigate the optical behaviour of biaxial members of the alunite family at different temperatures and search for possible phase transitions. Considering the potential use of crandallite-, beudantite- and alunite-group compounds as hosts for toxic heavy-metal waste. it would also be interesting to determine the maximum Sb solubility in Fe-members of these groups.

\section{Acknowledgements}

We thank Prof. E. Tillmanns, Vienna, for comments on the manuscript. This work was made possible by a Feodor-Lynen-Fellowship of the Alexander-von-Humboldt-Foundation, Bonn, Germany, to the first author. Part of the funds for this Fellowship were granted by the Australian Research Council (ARC) to Prof. T. J. White and Dr. A. Greeson (University of South Australia).
The ARC is also thanked for support of the crystallographic facility.

\section{References}

Barth, T.F.W. and Berman, H. (1930) Chem. Erde, 5 22-42. [cited in Foshag (1937)].

Baur, W.H. (1981) Interatomic distance predictions for computer simulation of crystal structures. In Structure and Bonding in Cristals (M. O'Keeffe and A. Navrotsky, eds.), Vol. II, Academic Press, New York, 31-52.

Birch, W.D. and van der Heyden, A. (1997) Minerals of the Kintore and Block 14 open cuts at Broken Hill, New South Wales. Austral. J. Mineral., 3, 23-71.

Blanchard, F.N. (1989) New X-ray powder data for gorceixite, $\mathrm{BaAl}_{3}\left(\mathrm{PO}_{4}\right)_{2}(\mathrm{OH})_{6} \cdot \mathrm{H}_{2} \mathrm{O}$, an evaluation of $\mathrm{d}$-spacings and intensities, pseudosymmetry and its influence on the figure of merit. Powder Diffraction, 4, $227-30$.

Blount, A.M. (1974) The crystal structure of crandallite. Amer: Mineral., 59, 41-7.

Brese, N.E. and M. O'Keeffe (1991) Bond-valence parameters for solids. Acta Crystallogr., B47, $192-7$.

Brown, 1.D. (1988) What factors determine cation coordination numbers? Acta Crystallogr., B44, 545-53.

Brown, I.D. and Altermatt, D. (1985) Bond valence parameters obtained from a systematic analysis of the inorganic crystal structure database. Acta Cristallogr., B41, $241-7$.

Brown, I.D. and Wu, K.K. (1976) Empirical parameters for calculating cation-oxygen bond valences. Acta Crvstallogr., B32, 1957-9.

Cowgill, U., Hutchinson, G.E. and Joensuu, O. (1963) An apparent triclinic dimorph of crandallite from a tropical swamp sediment in El Petén, Guatemala. Amer. Mineral., 48, 1144-53.

de Bruiyn, H., van der Westhuizen, W.A., Beukes, G.J. and Meyer, T.Q. (1990) Corkite from Aggeneys, Bushmanland, South Africa. Mineral. Mag., 54, 603-8.

de Meulenaer, J. and Tompa, H. (1965) The absorption correction in crystal structure analysis. Acta Cristallogr., 19, 1014-8.

Dunn, P.J., Peacor, D.R., Criddle, A.J. and Stanley, C.J. (1988) Filipstadite. a new Mn-Fe ${ }^{31}-\mathrm{Sb}$ derivative of spinel, from Långban, Sweden. Amer. Mineral., 73. 413-9.

Ferraris, G. and Ivaldi, G. (1984) $X-\mathrm{OH}$ and $\mathrm{O}-\mathrm{H} \cdots \mathrm{O}$ bond lengths in protonated oxyanions. Acta Crystallogr., B40, 1-6.

Fleischer, M. and Mandarino, J.A. (1995) Glossary of Mineral Species 1995. The Mincralogical Record 


\section{STRUCTURE OF ANTIMONIAN DUSSERTITE}

Inc., Tucson, USA.

Fleischer, M. and Mandarino, J.A. (1997) The first list of additions and corrections to the Glossary of Mineral Species 1995. Mineral. Record, 28, 425-38.

Foshag, W.F. (1937) Carminite and associated minerals from Mapimi, Mexico. Amer, Mineral., 22, 479-84.

Giuseppetti, G. and Tadini, C. (1980) The crystal structure of osarizawaite. Neues Jahrb. Mineral. Mh., $401-7$.

Giuseppetti, G. and Tadini, C. (1987) Corkite $\mathrm{PbFe}_{3}\left(\mathrm{SO}_{4}\right)\left(\mathrm{PO}_{4}\right)(\mathrm{OH})_{6}$, its crystal structure and ordered arrangement of tetrahedral cations. Neues Jahrt. Mineral. Mh., 71-81.

Giuseppetti, G. and Tadini, C. (1989) Beudantite $\mathrm{PbFe}_{3}\left(\mathrm{SO}_{4}\right)\left(\mathrm{AsO}_{4}\right)(\mathrm{OH})_{6}$, its crystal structure, tetrahedral site disordering and scattered $\mathrm{Pb}$ distribution. Neues Jahrh. Mineral. Mh., 27-33.

Hill, R.J. (1977) A further refinement of the barite structure. Canad. Mineral., 15, 522-6.

Hintze, C. (1933) Ifandhuch der Mineralogie. Vol. 1-4, Part 2, 721-41. Walter de Gruyter \& Co., Berlin.

International Tahles for X-rar. Crystallography (1974) Vol. IV, Kynoch Press, Birmingham, England, $558 \mathrm{pp}$.

Jambor, J.L. and Dutrizac, J.E. (1983) Beaveriteplumbojarosite solid solutions. Canad. Mineral., 21, $101-13$.

Jambor, J.L., Owens, D.R., Grice, J.D. and Feinglos, M.N. (1996) Gallobeudantite, $\mathrm{PbGa}_{3}\left[\left(\mathrm{AsO}_{4}\right)\right.$, $\left.\left(\mathrm{SO}_{4}\right)\right]_{2}(\mathrm{OH})_{6}$, a new mineral species from Tsumeb, Namibia, and associated new gallium analogues of the alunite-jarosite family. Canad. Mineral., 34, $1305-15$.

Kato, T. (1977) Further refinement of the woodhouseite structure. Neues Jahrb. Mineral. Mh., 54-8.

Kato, T. and Radoslovich, E.W. (1968) Crystal structures of soil phosphates. Trans. 9th Int. Congr: of Soil Science, Vol. II, Int. Soc. of Soil Science. Adelaide. Australia, 725-31.

Kharisun. Taylor, M.R., Bevan, D.J.M. and Pring, A. (1997) The erystal structure of kintoreite, $\mathrm{PbFe}_{3}\left(\mathrm{PO}_{4}\right)_{2}\left(\mathrm{OH} . \mathrm{H}_{2} \mathrm{O}\right)_{6}$. Mineral. Mag., 61, 123-9.

Lengauer, C.L., Giester, G. and Irran, E. (1994) $\mathrm{KCr}_{3}\left(\mathrm{SO}_{4}\right)_{2}(\mathrm{OH})_{6}$ : Synthesis, characterization, powder diffraction data, and structure refinement by the Rietveld technique and a compilation of alunite-type compounds. Powder Diffraction, 9, 265-71.

Lottermoser, B.G. (1990) Rare-earth element mineralisation within the Mt. Weld carbonatite laterite, Western Australia. Lithos, 24, 151-67.

Mandarino, J.A. and Grice, J.D. (1997) New minerals recently approved. Mineral. Record, 28, 397-400.

Martin. M., Schlegel, F. and Siemroth, J. (1994) The mining district Niederschlag near Oberwiesenthal: Rare copper arsenates from the Saxonian Erzgebirge. Lapis, 19 (4), 13-22. (in German)
Meagher, E.P., Gibbons, C.S. and Trotter, J. (1974) The crystal structure of jagowerite: $\mathrm{BaAl}_{2} \mathrm{P}_{2} \mathrm{O}_{8}(\mathrm{OH})_{2}$. Amer. Mineral., 59, $291-5$.

Molecular Structure Corporation (1993) teXsan - Single Crystal Structure Analysis Software, Version 1.6. Molecular Structure Corporation, The Woodlands, TX 77381, USA.

O'Keeffe, M. (1991) EUTAX, a Computer Program for Calculating Bond Valences. Dept. of Chemistry, University of Arizona, USA.

Olmi, F., Sabelli, C. and Trosti-Ferroni, R. (1995) The crystal structure of sabelliite. Eur. J. Mineral., 7. $1331-7$.

Palache. C., Berman, C. and Frondel. C. (1951) Dana's System of Mineralogy. 7th ed., Vol. Il. John Wiley, New York.

Radoslovich, E.W. (1982) Refinement of the gorceixite structure in $\mathrm{Cm}$. Neues Jahrb. Mineral. Mh. 446-64.

Radoslovich, E.W. and Slade, P.G. (1980) Pscudotrigonal symmetry and the structure of gorceixite. Neues Jahrb. Mineral. Mh., 157-70.

Rattray, K.J., Taylor, M.R., Bevan, D.J.M. and Pring, A (1996) Compositional segregation and solid solution in the lead dominant alunite-type minerals from Broken Hill, N.S.W. Mineral. Mag., 60, 779-85.

Schwab, R.G., Herold, H., Götz, C. and de Oliveira, N.P (1990) Compounds of the crandallite type: Synthesis and properties of pure goyazite, gorceixite and plumbogummite. Neues Jaluh. Mineral. Mh., $113-26$.

Scott, K.M. (1987) Solid solution in, and classification of, gossan-derived members of the alunite-jarosite family, northwest Queensland, Australia. Amer. Mineral., 72, 178-87.

Shannon, R.D. (1976) Revised effective ionic radii and systematic studies of interatomic distances in halides and chalcogenides. Acta Chstallogr., A32, 751-67.

Shannon, R.D. and Calvo, C. (1973) Refinement of the crystal structure of low temperature $\mathrm{Li}_{3} \mathrm{VO}_{4}$ and analysis of mean bond lengths in phosphates. arsenates, and vanadates. J. Solid State Chem., 6. $538-49$.

Sima, 1., Ettinger, K., Koppelhuber-Bitschnau, B. Taucher, J. and Walter, F. (1996) $\mathrm{Pb}_{3} \mathrm{Sb}(\mathrm{OH})_{6}$ $\left(\mathrm{AsO}_{4}, \mathrm{SO}_{4}\right)_{2} \cdot 3 \mathrm{H}_{2} \mathrm{O}$, a new mineral isotypic with fleischerite. Mitt. Österr. Mineral. Ges., 141, 224-5. (in German)

Smith, R.L., Simons, F.S. and Vlisidis, A.C. (1953) Hidalgoite, a new mineral. Amer. Mineral., 38. $1218-24$.

Süsse, P. and Tillmann. B. (1987) The crystal structure of the new mineral richelsdorfite, $\mathrm{Ca}_{2} \mathrm{Cu}_{5} \mathrm{Sb}(\mathrm{Cl}$ $\left.(\mathrm{OH})_{6} /\left(\mathrm{AsO}_{4}\right)_{4}\right) \cdot 6 \mathrm{H}_{2} \mathrm{O}$. Z. Kristallogr., 179, 323-34.

Szymański, J.T. (1985) The crystal structure of plumbojarosite, $\mathrm{Pb}\left[\mathrm{Fe}_{3}\left(\mathrm{SO}_{4}\right)_{2}(\mathrm{OH})_{6}\right]_{2}$. Canad. 


\section{U. KOLITSCHETAL.}

Mineral., 23, 659-68.

Szymański, J.T. (1988) The crystal structure of beudantite $\mathrm{Pb}(\mathrm{Fe}, \mathrm{Al})_{3}\left[\left(\mathrm{As}, \mathrm{S} \mathrm{O}_{4}\right]_{2}(\mathrm{OH})_{6}\right.$. Canad. Mineral., 26, 923-32.

Walenta, K. (1966) Contributions to the knowledge of rare arsenate minerals with special respect to occurrences in the Black Forest. Tschermaks
Mineral. Petrogr: Mitt., 11, 12I-64. (in German) Wise, W.S. (1975) Solid solution between the alunite, woodhouseite, and crandallite mineral series. Neues Jahrh. Mineral. Mh., 540-5.

[Manuscript received I Ma! 1998 :

revised I July 1998] 